\title{
A Small Literature in the Service of Nation-Building: the Estonian Case ${ }^{1}$
}

\author{
ARNE MERILAI \\ KATRE TALVISTE
}

\begin{abstract}
The idea of Estonia's cultural and national self-sufficiency emerged in the nineteenth century. The contribution of writers and poets was essential to this development. Literature anticipated not only cultural, linguistic, and artistic, but also the economic and political emancipation of Estonians. Cultural practices leading to this emancipation were largely based on Baltic German models; many key elements to the independent Estonian national identity are of foreign origin. On the one hand, the nineteenth-century nationbuilding could therefore be described as self-colonization. On the other hand, it rather created a new nation than transformed a preexisting one, since the very concept of national identity was introduced by this process. Through various political and cultural upheavals, the most influential authors from this seminal period of the Estonian modern culture have remained iconic to this day. The traditional identification with them is so strong that the tentative origins of the nation and the identitary struggles of the national poets themselves may often be forgotten and the personal and individual nature of their contribution downplayed.
\end{abstract}

Keywords: Estonian literature; small literatures; nation-building; self-colonization; Romanticism

\section{Nation-Building in Nineteenth-Century Estonia: from Poetic Figures to Political Dreams}

Romanticist ideas of the early nineteenth century contributed to the raise of national awareness in many cultural communities, which led to a cultural emancipation and modernization, and eventually to the formation of a number of new independent nation states by the beginning of the twentieth century.

1 This study was supported by the Estonian Ministry of Education and Research (IUT20-1), and by the (European Union) European Regional Development Fund (Centre of Excellence in Estonian Studies).

DOI: https://doi.org/10.12697/IL.2019.24.1.18 
MERILAI, TALVISTE

In Estonia, one of the nations and countries emerged from the Romantic era, this development was pretty much aligned with that of the written word, the evolution of literary tradition. Here we shall briefly explore these relations between poetical and political thought, and the transformation of individual creativity into collective imagery and identity.

Much credit must be given to early Estonian literature for gradually deepening the expression of the idea of personal and social freedom. One can do so even in the Heideggerian sense of the poetic delivering of being, the inauguration of existence, or Foucaultian sense of the social construction as a certain version of it. In the Estonian case, the idea of freedom began to manifest itself predominantly as the ideal of the farmer's self-sufficiency, the most desirable state that the peasants could ever dream of - to become a full master of one's own land and dwelling, then, to reestablish the natural democracy of the more or less equal neighbors on the county level. And consequently nationwide, in a cultural and economic sense. This was the pivot point around which every other thought has spun during the last two centuries. Since the thirteenth century, Estonian-speaking districts below the Gulf of Finland, together with Latvians, were subjected to the German, Danish, Swedish and even Polish authorities, and after the Great Northern War to the Russian Empire. However, the local nobility was always predominantly Baltic German and the ruling language German. The Estonian-speaking population consisted of peasants living in a harsh serfdom.

Influenced by the emancipatory movements during the era of the French Revolution, but mainly due to the economic lag in the Russian empire, caused by the incapable feudal system which had minimized the incomes of the manors and state accordingly, and the steady impoverishment of the peasantry, the Russian Czar came up with an experimental abolition of serfdom in the Baltic provinces: in 1816 for the province of Estland and 1819 for Livland, followed by some supplementary reforms. However, as the ultra-conservative Baltic aristocracy by whom the Russian governance was infiltrated, strongly resisted this delayed initiative, the peasants never got the land necessary for their living. As a result, the era of the tenant serfdom began, which occasionally led even to more dire straits with continuing corporal punishments. As late as in the 1860s, the peasants finally received the right to change their domicile, granted with an opportunity to pass from work-rent to money-rent with the prospect of full ownership of their farms. Prior to that, until the nineteenth century, a healthy male field hand, skilled craftsman or a whole family (equivalent to a horse as a rule of thumb) had been considered much cheaper than Uncle Tom in New Orleans' slave market: up to 100 rubles compared with around 1000 dollars 
A Small Literature in the Service of Nation-Building: the Estonian Case

(as a good horse cost about $100 \$$ in USA). ${ }^{2}$ Postcolonial discussions seem to ignore the fact that "white slavery" was a reality, too, even in modern Europe. ${ }^{3}$

In such circumstances, the European Enlightenment had started to penetrate the Baltic provinces at the end of the eighteenth century. Human liberty and rights, vernacular languages and folklore, Herder and Sturm und Drang inspired the occasional Baltic German humanists, and some of them even turned into Estophiles. The historical chronicles were discovered, which described the conquering of the land long ago. This revived interest led to the emergence of the vernacular literature in the context of Sentimentalism, pietism and early Romanticism.

The first poet of Estonian origin who got clearly contaminated with the European virus of freedom was Kristian Jaak Peterson (1801-1822). This young bard, often regarded as a genius, was the herald of the Estonian written poetry, which had moved away from the old folk song. His poems, which, alas, remained mostly in manuscript form for a century, are charged with a sense of anticipation of something great that would last throughout the ages. Peterson's lines "Why should not my country's tongue, / Soaring through the gale of song, / Rising to the heights of heaven, / Find its own eternity?" (Nirk 1987: 50) have been emblematic in Estonia as a bold manifest of the awakening nationhood. However, one should probably interpret them in more general terms: it is not the Estonian language in particular that Peterson has in mind, but rather all the languages in the world, in front of God's eyes, with Estonian among the other. The young poet was still an idealistic Baltic Estophile rather than a clear-cut Estonian nationalist - he was only declared to be one only a hundred years later (see Merilai 2004a).

The next step forward was made by the society Gelehrte Esthnische Gesellschaft and two medical doctors of peasant origin, Friedrich Robert Faehlmann (1798-1850) and Friedrich Reinhold Kreutzwald (1803-1882). The most outstanding output of this Society was the national epic Kalevipoeg (see Hasselblatt 2016). The idea of the national epic was launched by Georg Schultz, alias Dr. Bertram, a Baltic-German humanist who was the first one to declare: "Give them an epic and a history and everything is won!" (Hasselblatt 2016: 26).

2 By the way, the American Civil War in the 1860s turned out to be conducive to Estonia's national awakening, as the prices of linen sky-rocketed in Europe which opened the way for the peasantry to purchase their freedom from the manor (Merilai 2014: 379).

3 Technically, the term is 'serfdom', which constituted proper bondage to the manor and included duties to the state with some limited movable chattel allowed to the serfs. But still, it meant nothing but slavery, and the Estonians reflect upon it so. In Finland or Sweden, at the same time, serfdom was never established. 
Under the influence of the Finnish epic Kalevala, Faehlmann, founder of the learned society, started to envisage the initial contours of an Estonian epic, Kalevipoeg - at first in prose. He presented his Ancient Tales, where he had converted the figure of the son of Kalev, known in the Estonian folklore rather as a malevolent brutal giant prone to rape, into an ancient king of the Estonians who fights for his country's liberty. In his public lectures and heated argument with barons in the 1840s, Faehlmann firmly explained to his fellow countrymen that the Estonians had been enslaved (Raud 1965: 484-485). They were excluded from the trade, industry, and politics because they were not of noble origin. Only their language was allowed as a sign of slavery, a sign that ensures the wall between the masters and servants.

Kreutzwald shared Faehlmann's views as well as his skepticism regarding the prospects of their nation's flourishing, not to mention its prospects of becoming fully independent. They rather tried to erect a memorable, albeit mostly fictional monument to the country's past glory in an effort to preserve some dignity. In the later Estonian discourse the following line from Kreutzwald's epic became emblematic: "I see a dwelling rising from afar". This line has been taken as an encouraging prophecy of future sovereignty. However, the author himself was fully retrospective at this point: in his imagination, it was the home rising in the lost and misty past to become depicted by him, and not the bright omen for the future.

Ironically but luckily, Kreutzwald's heavily Ossianistic epic - structurally, it is rather a lyric-epic text ${ }^{4}$ - was his most important accomplishment aimed at nation building. We do not know any other European Romantic epic that would have emphasized, with such intensity as Kalevipoeg, a patriotic ideal. There would be, of course, the Lačplessis (The Bearslayer, 1888) of the Latvians. A parallel could be found also in The Lusiads (by Luis Vaz de Camões), from the European Renaissance, as it was also designed to inspire a nation by its great deeds in the past, to project its future (see Talvet 2011). One may even claim that Kalevipoeg shaped a nation's identity in a way the Book of Mormons by Joseph Smith founded his famous community in the 1830s (Merilai 2004b: 242). Especially in the light of the many foreign occupations and repressions they had to endure, for the Estonian people Kreutzwald's great work was essential: in the forging of the national awakening movement during the

Why lyric-epic? Firstly: "Kalevipoeg was shaped by the poetics of romantic balladry. This can be proved by its author's devotion to the ballad; in addition, many a lyro-epic folk song has been integrated into Kalevipoeg." And secondly: "[a] ballad-like lyrodramatical-epical structure bears upon the work which gave rise to a new form: the lyro-epic epic.” (Merilai 2015: 497) 
nineteenth century, and in the persistence of national memory and the ideal of freedom during the twentieth century. Thanks to him, Estonian literature, along with its rapidly evolving written language, became hard to ignore by the rest of the world.

The post-Kreutzwaldian national awakening movement brought new schools, cultural and agricultural societies, textbooks and books of literature, choir songs and brass band festivals; much of it, however, in the mold of the German role models. Self-colonizing or not, but the Estonians learned and sung themselves into a nation with an overall literacy. It has been pointed out by the Finnish writer Aino Kallas (1999: 77) who relies on the recollections of the participants that the Estonians actually felt for the first time that they formed a collective which emotionally belonged together at the first Song Festival in Tartu. This important event, dedicated to the fiftieth anniversary of the abolition of serfdom, was organized in 1869 by the editor of the weekly Postimees, Johann Voldemar Jannsen. The next generation would be even more radical: Carl Robert Jakobson, editor of the newspaper Sakala, and Jannsen's daughter Lydia, to whom Jakobson gave the pen-name Koidula, represent the heyday of the national awakening movement. Koidula (1843-1886) became the first author of a rich female poetry in Estonian. Her poems expressed fastgrowing national sentiments (Puhvel 1995).

For the most part, the literature that followed conformed to the general pattern of the national movement. The wave of patriotic idealism was overwhelming. A good example of the mentality is expressed by the title of the narrative by a schoolteacher Jakob Pärn Oma tuba, oma luba (My Room, My Right, 1879). The story represents the success of evolutionary decolonization, driven by the desire of the people to become landowners on their own. However, as Jannsen had said: you may be free to go wherever you wish, but if you have no room and you get hungry, you must bend yourself under the yoke of the taxes - and your freedom turns bitter.

Apart from the sketches of village life expressing longing for economic independence, the late nineteenth century also saw a wave of Romantic historical fiction, launched by Eduard Bornhöhe's (1862-1923) narrative Tasuja (The Avenger, 1880) which depicted the ancient struggle for liberty in a spirit of youthful enthusiasm. However, none of these dreams of freedom went as far as to envision a political independence for the nation. In this respect, Juhan Liiv's (1864-1913) poetry offers a clear and widely known exception. "Once there will be the Estonian state!" he declared in a poem from 1905 that remained in manuscript for two decades. Even the Young Estonia movement which initiated the modernization of literature since 1905, with their famous slogan by the poet 
MERILAI, TALVISTE

Gustav Suits - "Let us remain Estonians, but let us become Europeans, too!"never reached a notion beyond provincial autonomy. Quite the contrary, as late as in 1918, the same year when Estonia declared itself fully independent, Suits published a booklet under the title The Estonian Labour Republic (Eesti Töowabariik) promoting the idea of a federation within the frame of a changing empire. Similarly, the first Estonian novelist, socialist Eduard Vilde (18651933), was no better a visionary.

In turn, it is characteristic that the declaration of the independent democratic republic, the Manifest for all the Peoples of Estonia (February 21, 1918) relied strongly on the ideas expressed by the epic Kalevipoeg from half a century ago:

The Estonian people have during the centuries never given up the desire for independence. From generation to generation a secret hope has lasted that despite the dark night of slavery and the rule of violence foreign nations one day there comes the time for Estonia when "all spills at both their ends will start outright to flare out bright" and that "surely Kalev will then come home to bring his children fortune true.” Now the time has come. (Manifesto... 1918)

Therefore, at the first stages, before and during the national awakening, literature was clearly the main agent to express the idea of national independence, although mainly in a cultural, economic, or personal sense. If the Estonians cannot be a great nation in number, at least they can be "great in spirit", as it was summoned by the folklore collector pastor Jakob Hurt in 1870 - for a nation of a higher cultural level could not be deprived of its identity (Laar et al. 1989: 340). However, writers failed to develop the idea to its ultimate political consequences. Thus, pre-politically, literature was leading in terms of patriotism, but later on it became more marginalized as the national movement took the literary ideas over and further. In Martin Heidegger's terms: "the act that founds a political state", alongside "the essential sacrifice", may also be a poetical deed in which "truth occurs" (Heidegger 1993a: 186-187). Or, as it was put by Friedrich Hölderlin: "poetically man dwells on this earth" (Heidegger 1993b: 340).

All this, of course, raises the question of cultural self-colonization: the hybridization of the traditional mentality and lifestyle and the substitution of former patterns for new, often foreign, but more prestigious ones, which, at the same time, were the guarantees for the desired liberty. There is a tendency in postcolonial discourse to take self-colonization for something negative; however, in terms of Norbert Elias (see Elias 1978), this aligns with the process of general civilization to be considered rather positively. Surely the Estonians 
A Small Literature in the Service of Nation-Building: the Estonian Case

are today in many respects a different nation compared to their ancestors they neither speak, think, write, work, eat, sing, dance nor make love in the manner they used to do - yet they are confident enough with their modern achievements and improvements. To appreciate the full complexity at work here, it is important to understand the conflicting nature self-colonization holds for the Estonians: it diminishes and at the same time deepens their collective sense of self.

\section{Poet as a Personification of Cultural Identity}

The literary works that propelled the national awakening movement along were largely the fruit of individual creative endeavours, as literary works always are. Their efficiency in the context of nation-building was, however, largely due to their appropriation by the emerging nation and to the quick canonization of several remarkable nineteenth-century poets - Peterson, Kreutzwald, Koidula and Liiv - as collectively recognized 'cultural saints' (see Dović 2012).

The canonization of Kreutzwald and Koidula began during the national awakening, that is, during their lifetime. Since Carl Robert Jakobson's influential textbook Kooli lugemise raamat (Reading Book for School, 1867), their texts became part of the basic literary education. Juhan Liiv's texts appeared quite early as well, in the next generation's similar basic reading anthology for schools, Mihkel Kampmaa's Kooli lugemiseraamat (1905). Peterson's poetry, however, had remained unpublished throughout the nineteenth century. It was only discovered and made available to the public by the Young Estonia movement over the first decade of the twentieth century. Considering this fact, the notable attention that Mihkel Kampmaa gives to Peterson in the first volume of his 1912 history of Estonian literature published is also a sign of almost instant canonization.

Kampmaa's textbook also shows clear signs of a strong identification with Peterson, of a certain backward projection of identity:

With his youthful courage, our first Young Estonian frees himself in the field of poetry from the goals and forms that our literature is still enslaved to today, he draws his poetic material mostly from his own feelings and imagination, and becomes Estonia's first independent poet of passion and sentiment, who often tries to imitate the form of Estonian folk songs. (Kampmann 1912: 276) ${ }^{5}$

5 Here and henceforth quotes translated by Katre Talviste. 
MERILAI, TALVISTE

With Kreutzwald, Kampmaa makes an effort to avoid such identification. He describes the admiration of several earlier critics and Kreutzwald's contemporaries, but doesn't wholly share it. Despite such a reservation, he doesn't contest Kreutzwald's canonical status and cultural importance:

The next, less exalted generations have no right nor desire to disregard the shortcomings of Kreutzwald's work or to praise his weaknesses, but they will try to understand the true value of his better works. Kreutzwald has powerfully and boldly removed the restraints from our people's spirit, has saved our ancestors' most beautiful memories from oblivion, brought them to light and made us cherish them, gained respect for the name of Estonians from the whole world and built the foundation of our national self-awareness. He's the Kalevipoeg of our time, a mighty spiritual hero who fights for spiritual freedom with a verbal sword and opens a new cultural era in Estonia. (Kampmann 1913: 58)

Kampmaa's attempt to take a somewhat revisionist, critical look at the nineteenth-century cultural saints was apparently not quite wholehearted. His praise of Koidula is openly enthusiastic. He underlines her great and unique gift and the very emotional quality of her poetry. These potentially individualistic qualities are very clearly related to collective values and goals: "With her poetry, Koidula tried to lift Estonian hearts toward the light, the spiritual dawn, to wake them from their torpor, to revive and warm them." (Kampmann 1913: 92)

The same applies to Juhan Liiv, once Kampmaa tackles his life and work in the third volume of his literary history:

We have no other writer as close to Estonian life, particularly to its tragic side, as Juhan Liiv. Crowned himself by fate with thorns of pain, his enlightened spirit entered the deepest corners of the people's sad soul, pictured subtly and emphatically an Estonia cruelly treated by fate, suffering on the outskirts of the bog of History. Himself a poet with a broken soul, he looked for the threads of the Estonian fate, the Estonian pain, the Estonian tragedy. And he understood so well the depths of the Estonian soul, its mysterious movements, captured the fatality and tragedy so characteristic of our life in his works, because his own life was so deeply tragic. (Kampmann 1923: 23)

Kampmaa's four-volume history of Estonian literature (1912-1936) was the first thorough study of the subject, and its wide scope was not matched for several decades. For his school anthology (several editions and revisions from 1905 to 1921), various alternatives appeared in the 1920s and 1930s, but his considerable influence on Estonian literary pedagogy and canon at their initial stages is undeniable. Controversies about them obviously emerged later, as the 
field developed, but at least as far as the four national poets are concerned, the tradition he had established continued throughout the twentieth century and is still very much alive today.

The strong identification that was obvious already in Kampmaa's literary history also continued. The critic's contemporary values and agendas are attributed to the four poets, and their preoccupations are perceived as the critic's own. Also, the distinction between the poets' lives and their poetic and fictional universe is not really clear. The same could be stated regarding the distinction between personal, emotional, cultural, and political themes in their work. Such a synthetic perception is generally characteristic of Romanticism. The paradox here lies in the fact that none of these four poets was as profoundly Romantic in his or her writings or thoughts as their readers have been in later interpretations. Compared to the other three, it is perhaps Peterson whose models, poetics and self-image are the closest to the mainstream European Romanticism, especially in his poems written in German. However, his personal diary reveals a spirit much more profoundly marked by his classical education and the moral and intellectual thought of the Enlightenment. The discovery of the cultural diversity of the world is clearly the part of Romanticism that has inspired him most. Peterson yearns to know and understand languages and cultures in their uniqueness and to elevate the symbolic status of his ancestors' language. As an individual, however, he longs for balance, knowledge, and fulfilment that come from moderate expectations and harmonious relationships.

As suggested above, Peterson's ideals were not so much national as universal, even though the universe he praises is culturally diverse. Still, it is obvious from some poems and diary entries that Estonia, or Our-Land (Meiemaa, Peterson 1976: 103), as he called it, had a strong symbolic meaning to him, which was not based on simple personal experience, but on an idea. In a poem dating from 1819, he says farewell to "our land" when leaving it to go back to his childhood home and to his parents in Riga (Peterson 1976: 59). His personal origins were in a different place from the land he referred to as "ours" and where the Estonians lived, although officially both were in the same province of Livonia. Peterson's identification with his symbolic homeland thus predated its geopolitical unity and identity. The fact that he did not have another name for it apart from "our land", poetically underlines this fact.

At that time, the community that Peterson identified with also lacked an ethnonym in its own language. At the beginning of the nineteenth century, the Estonian-speaking population of Estland and Livland shared the social identity of peasants and, undoubtedly, a practical awareness of the linguistic and 
cultural differences from other social groups. Developing that awareness into a national identity was the work of Kreutzwald's and Koidula's generations in the 1850s and 1860s. Their own longing for such an identity was considerably clearer than Peterson's, but it is also obvious from their writings that they were aware of the fact that the object of their longing was yet to be constructed. The identity they were speaking for was not the one they started out with in life, and, as a work in progress, it involved a lot of uncertainty.

Their correspondence offers an insight into this situation. It started in 1867, at the initiation of Koidula. She wrote to Kreutzwald, already a living legend in the national movement, to contest some satirical remarks Kreutzwald had published about female writers. The correspondence (published in Kreutzwald 1962) developed into a rich exchange of ideas and a close friendship. All through the six years that it lasted, they alternated between Estonian and German, depending on the complexity of topics and lines of thought. On the one hand, their use of Estonian went well beyond a symbolic gesture, they made systematic efforts to develop the capacities and functions of the emergent national and literary language. On the other hand, the efforts were still in such early stages that the Estonian language did not cover their own needs of communication in all fields.

Juhan Liiv's letters to his fiancée Liisa Golding written about thirty years later indicate a changed situation. Partly due to his lesser opportunities for formal education, Liiv clearly has Estonian as the dominant language. German is still present in his letters, in the form of quotes, occasional words or puns, but very rarely used for longer passages. It is also abundantly present in his reading material, but has become a more passive asset than it had been for his predecessors. Liiv even complains about his difficulties with learning German (Liiv 2000: 19). Liiv's letters reflect the unquestionably multilingual and multicultural society he lived in, but they also show that a rather complex cultural and literary environment that functioned mostly in Estonian had emerged.

It is also notable in Liiv's letters that he expresses his dreams of purely personal independence and fulfilment (newspaper ownership, financial stability, marriage, literary fame - the latter being the only one he achieved, albeit very late in life and posthumously) more strongly than Kreutzwald or Koidula, and is more concerned about the lack of personal recognition writers receive from their contemporaries and from posterity. Of course, neither Kreutzwald nor Koidula were free from that concern or insensitive to the public's response to their work (Undla-Põldmäe 1981: 98, 225). Nevertheless, their identification with the national cause seems stronger than Liiv's, who rather has personal ambitions within the national cause. 
Kreutzwald, Koidula, and Liiv lived to see a certain progress of their dreams for their nation and to receive recognition for their contribution, but this recognition was not entirely compatible with their self-image as poets and public figures, and certainly did not include the more personal aspects of their life. On the contrary, as their nation progressively turned them into cultural icons, the personal aspects that did not fit the image were forgotten or redesigned. It was particularly salient in Koidula's case. In 1873, she married Eduard Michelson, a medical doctor of Latvian origin and Baltic German upbringing, who did not speak Estonian and was not a part of the Estonian national movement. The couple moved away from Estonia, to Kronstadt, where Michelson was assigned to work. The contemporaries' reaction to Koidula's life choice was hostile. In later years, a rather demonized interpretation of Michelson's character developed along with a somewhat exaggerated image of Koidula's misery in her "exile".

Considering the fact that Koidula was also buried in Kronstadt, this image paradoxically turned into a powerful asset for Soviet propaganda during and after the Second World War. A group of pro-Soviet intellectuals and politicians visited Koidula's grave in 1944. The poet Johannes Vares-Barbarus, who had become the chairman of the Supreme Soviet of Estonia after the Soviet invasion of 1940, made a speech there. The speech was later published in several editions of a Stalinist era sixth-grade textbook to accompany Koidula's poems (VaresBarbarus 1949; 1950). It combines the pathos of Estonian national awakening and of Soviet and Stalinist propaganda, linking them via the anti-German sentiments that were generally instrumental in the forced reconstruction of the Estonian identity that the Soviet occupation undertook. Koidula's reburial, which took place in 1946, was made to serve the same purpose. It was carried out with great pomp and considerable media-coverage. Important political and cultural figures were involved. A two-hour documentary film was made. The aforementioned textbook, published only a few years after the reburial, already instrumentalized the event for educational purposes: one task given to pupils in the chapter about Koidula is to explain when and by whom Koidula was reinterred in Estonia, at the Tallinn Metsakalmistu cemetery (Selmet 1950: 144). ${ }^{6}$ This kind of appropriation of national symbols for the Soviet cause, to

6 Later on, not only Koidula's own anniversaries were celebrated, but also that of the reburial. Even today, the event keeps drawing attention. Henno Sepp, who found the grave after the war and witnessed the reburial, has given several interviews about it to the Estonian press in recent years (Suviste 2015; Aarma 2016). Journalists are intrigued by the fate of several bones and some jewelry, supposedly stolen by a doctor who participated in the reburial. The issue of the separation of the family remains 
make the occupation appear supportive of the local culture and its continuity, was a fairly regular practice. It was, of course, selective: only symbolic figures that could easily be reinterpreted in a pro-Soviet manner were promoted. Nineteenth-century cultural saints who were all long dead (and thus could not by their own actions undermine such reinterpretations) and had been involved in the early cultural emancipation (which was easy to represent as aggressively anti-German) were perfect material for this type of propaganda. Later on, this demagogic device was also turned against the regime: in the late 1950s, Estonian writers and intellectuals began to make use of the Soviet rhetoric in order to subtly criticize the regime and to discuss topics (including literary matters) that were officially not acceptable.

The ideological manipulations of authors' prestige do not only serve the ends of the manipulators, but also guarantee the authors' continued prestige and accessibility to the public. Even the Stalinist period, which otherwise was the most destructive for the continuity of culture and identity in Estonia, left the status of the four great nineteenth-century national poets untouched, having found ways to exploit it. Their texts could still be read independently from the propagandist agenda that allowed them to be available. They could also be read in a completely opposite sense to the propagandist interpretation as a confirmation of cultural independence and national awareness.

The nineteenth-century poets' dream of an independent Estonian identity has been forceful enough to carry the nation they imagined through several difficult historical moments. However, the strong collective identification with them that has made it possible has also made it difficult to see their own life and work independently from that particular cause and to realize that nation-building was not necessarily an inevitable process they represented, but rather one that they set in motion by their creative aspirations and efforts. Such a considerable impact of an individual contribution on a literary tradition and the collective self-image it carries may be characteristic of emergent national literatures in general, not only of small literary fields, when one thinks of Dante's, Shakespeare's or, more recently, Walt Whitman's role in their respective literary traditions. A further comparative study of differently sized and structured literary fields would be

has gained increasing attention and inspired debates. All these motives are used by the postmodernist writer Mati Unt in his novel Doonori meelespea (Unt 1990, English title: Diary of a Blood Donor, translation by Ants Eert, Unt 2008), which tackles the issues of identitary stereotypes. In Unt's novel, Koidula and Michelson appear as vampires. They prey, albeit unwillingly and only out of necessity, on the people that have symbolically preyed on them for over a century, and seek to settle in a peaceful and private life together. 
A Small Literature in the Service of Nation-Building: the Estonian Case

interesting to determine to what degree this kind of personal impact continues to influence an already established literary tradition.

\author{
Arne Merilai \\ arne.merilai@ut.ee \\ Tartu Ülikool \\ Ülikooli 16-110 \\ 51014 Tartu \\ EESTI / ESTONIA \\ Katre Talviste \\ katre.talviste@ut.ee \\ Tartu Ülikool \\ Ülikooli 16-113 \\ 51014 Tartu \\ EESTI / ESTONIA
}

\title{
Works Cited
}

Aarma, J. 2016. Kas Lydia Koidula selgroolüli maeti hoopis lillepeenrasse?. - Maaleht, 11.02, http://maaleht.delfi.ee/news/maaleht/uudised/kas-lydia-koidula-selgroolulimaeti-hoopis-lillepeenrasse?id=73632111 (07.01.2019).

Dović, M. 2012. The Canonization of Cultural Saints: An Introduction. - S. Stojmenska-Elzeser, V. Martinovski, eds., Literary Dislocations / Déplacements littéraires / Книжевни дислокации. Skopje: Institute of Macedonian Literature, 557-569.

Elias, N. 1978. Über den Prozess der Zivilisation: Soziogenetische und Psychogenetische Untersuchungen. 1. Band. Wandlungen des Verhaltens in den weltlichen Oberschichten des Abendlandes. Frankfurt am Main: Suhrkamp.

Hasselblatt, C. 2016. Kalevipoeg Studies: The Creation and Reception of an Epic. Studia Fennica Folkloristica, 21. Helsinki: Finnish Literature Society, SKS.

Heidegger, M. 1993a. The Origin of the Work of Art. - M. Heidegger, Basic Writings: from Being and Time (1927) to The Task of Thinking (1964). Ed. David Farrell Krell. New York: Harper San Francisco, 143-212.

Heidegger, M. 1993b. The Question Concerning Technology. - M. Heidegger, Basic Writings: from Being and Time (1927) to The Task of Thinking (1964). Ed. David Farrell Krell. New York: Harper San Francisco, 311- 341.

Laar, M., Saukas, R., Tedre, Ü., eds. 1989. Jakob Hurt 1839-1907. Tallinn: Eesti Raamat.

Kallas, A. 1999. Tähelend: eesti poetessi Koidula elulugu. Trans. Ants Paikre. Tallinn: Eesti Raamat. 
MERILAI, TALVISTE

Kampann, M. 1912. Eesti kirjanduseloo peajooned, I. Tallinn: August Busch. Kampann, M. 1913. Eesti kirjanduseloo peajooned, II. Tallinn: August Busch.

Kampann, M. 1923. Eesti kirjandusloo peajooned, III. Tallinn: August Busch. Kreutzwald, F. R. 1962. Kirjavahetus, V. Tallinn: Eesti Riiklik Kirjastus.

Kreutzwald, F. R. 2011. Kalevipoeg: Eesti Rahvuseepos. / Kalevipoeg: The Estonian National Epic. Trans. T. Kartus, comm. H. Mürk, D. E. Gay, ill. G. Neeme. TartuTallinn: Eesti Kirjandusmuuseum / Estonian Literary Museum, Kunst.

Liiv, J. 2000. Mu kallis Liisi. Tartu: Ilmamaa.

Manifesto to the Peoples of Estonia. 1918. https://en.wikipedia.org/wiki/Estonian_ Declaration_of_Independence (07.01.2019).

Merilai, A. 2004a. Genius of Estonian Poetry - Kristian Jaak Peterson. -ELM: Estonian Literary Magazine, No. 19, Autumn, 4-9, http://earlyelm.estinst.ee/ issue/19/genius-estonian-poetry-kristian-jaak-peterson/ (07.01.2019).

Merilai, A. 2004b. Eepos - Pikem (Pigem) Lugulaul. - Keel ja Kirjandus, 4, 241-250, 320.

Merilai, A. 2014. The Ages of Dickens in Estonian Literature: Some Comparative Perspectives with a Marxist Exposure. - Interlitteraria, 19-2, 372-387. DOI:10. 12697/IL.2014.19.2.10.

Merilai, A. 2015. Kalevipoeg: Aspects of Genre and Authorship. - Journal of Baltic Studies, Vol. 46, No. 4, 497-510. DOI: 10.1080/01629778.2015.1027936.

Nirk, E. Estonian Literature: Historical Survey with Biobibliographical Appendix. 2 Edition. Trans. A. R. Hone, O. Mutt. Tallinn: Perioodika, 1987.

Peterson, K. J. 1976. Laulud. Päevaraamat. Tallinn: Eesti Raamat.

Puhvel, M. 1995. Symbol of Dawn: The Life and Times of the $19^{\text {th }}$-Century Estonian Poet Lydia Koidula. Tartu: Tartu University Press.

Raud, L. 1965. Friedrich Robert Faehlmann. - Eesti Kirjanduse Ajalugu, I. Ed. by A. Vinkel. Tallinn: Eesti Raamat, 471-509.

Selmet, A. 1950. Kirjanduse õpik-lugemik 6. klassile. Tallinn: Eesti Riiklik Kirjastus.

Suviste, M. 2015. Võõrsilt kodumulda: kuidas Lydia Koidula ümber maeti ja mis saab Marie Underist. - Ôhtuleht, April 4, http://www.ohtuleht.ee/672754/voorsiltkodumulda-kuidas-lydia-koidula-umber-maeti-ja-mis-saab-marie-underist (07.01.2019).

Talvet, J. 2011. Kalevipoeg, a Great European Epic. - F. R. Kreutzwald, Kalevipoeg: Eesti rahvuseepos. / Kalevipoeg: The Estonian National Epic. Tartu-Tallinn: Eesti Kirjandusmuuseum / Estonian Literary Museum, Kunst, 504-510.

Undla-Põldmäe, A. 1981. Koidulauliku valgel. Uurimusi ja artikleid. Tallinn: Eesti Raamat.

Unt, M. 1990. Doonori meelespea. Tallinn: Kupar.

Unt, M. 2008. Diary of a Blood Donor. Champaign and London: Dalkey Archive Press.

Vares-Barbarus, J. 1949. Koidulat külastamas. - A. Selmet, Kirjanduslik lugemik VI klassile. Tallinn: Pedagoogiline Kirjandus, 283-287.

Vares-Barbarus, J. 1950. Koidulat külastamas. - A. Selmet, Kirjanduse õpik-lugemik 6. klassile. Tallinn: Eesti Riiklik Kirjastus, 140-144. 